\title{
Mak Nyahs in Malaysia: Does HIV/AIDS Knowledge Really Reduce HIV-Related Risk Behaviours? \\ Maliya S. ${ }^{a}$, Zul A.R. ${ }^{a}$, Irwan M.S. ${ }^{b}$, Samsul D. ${ }^{c}$, Zakiah M.S. ${ }^{d}$, Rafidah H.M. ${ }^{\text {e }}$ \\ Level 14, Fakulti Perubatan dan Sains Kesihatan, Universiti Sains Islam Malaysia \\ bInstitut Pengurusan Dan Penyelidikan Fatwa Sedunia (INFAD), Universiti Sains Islam Malaysia, \\ 'Department of Family Medicine, Kulliyyah of Medicine,IIUM Kuantan Campus \\ ${ }^{d}$ Family Health Development Division,Adult Health Sector, Kementerian Kesihatan Malaysia, \\ 'Level 13, Fakulti Perubatan dan Sains Kesihatan, Universiti Sains Islam Malaysia
}

\section{ABSTRACT}

Introduction. Male-to-female transgender individuals are known as mak nyahs in Malaysia. Akin to many other countries, mak nyahs face discriminations in securing proper employment, thus many end up in sex trade, exposing them to HIV-related high risk behaviours. This paper aims to investigate the knowledge, attitude, and risk behaviours in HIV/AIDS among mak nyahs in Malaysia. Method. Validated questionnaires in local language were used. Knowledge, attitude, and HIV-related risk behaviours were measured. With respondent-driven sampling method, 54 subjects participated in the survey. IBM SPSS was used for data analysis. Results. Majority of the subjects reported to have HIV-related sexual risk, although only a quarter were sex workers. Misconceptions still remained among the subjects. Inconsistent condom use was common. Adequate knowledge did result in better attitude towards HIV/AIDS. However, multiple regression analysis showed that subjects with higher knowledge in HIV/AIDS tend to have higher sexual risks $(B=0.320, p=$ 0.030). Conclusion. Educating the transgender community about HIV/AIDS does not seem to adequately reduce the HIV-related sexual risks. Other approaches, i.e. socio-cultural values and religious practices may be effective to instil higher levels of awareness and self-responsibility in this community to eliminate HIVrelated high risk behaviours.

KEYWORDS: male-to-female transgender, MTF, HIV, AIDS, sex worker

\section{INTRODUCTION}

Transgenders can be defined as individuals who transiently or persistently identify with a gender different from their natal gender. ${ }^{1}$ In Malaysia, the population of male-to-female transgenders has been estimated to be around $50,000 .^{2}$ Studies in Malaysia suggested that majority of transgenders in Malaysia are Malays (about $80 \%$ ) and also are Muslims. ${ }^{3,4}$ The local term used to address male-to-female transgenders is mak nyah.

Corresponding author:

Assoc. Prof. Dr. Rafidah Hanim Mokhtar

Level 13, Fakulti Perubatan dan Sains Kesihatan,

Universiti Sains Islam Malaysia

Menara B, Persiaran MPAJ,

55100 Kuala Lumpur, Malaysia

Phone: +60 13-932 2277

Fax : +60 3-4289 2477

Email :rafidahhanim@usim.edu.my
Globally, transgender people belong to one of the key populations at high risk of HIV infection, ${ }^{5}$ with the HIV prevalence of $19.1 \%$ worldwide, and are 48.8 times more likely to be living with HIV compared to adults of the general population. ${ }^{6}$ In Malaysia, based on findings from the Integrated Biological and Behavioural Surveillance (IBBS) studies in 2012 and 2014, the HIV prevalence among the mak nyah community appears to be increasing, from $4.8 \%$ in 2012 to $5.6 \%$ in $2014 .^{7}$ In Kuala Lumpur, the HIV prevalence among mak nyah has been recorded as high as $19.3 \% .^{5}$

Globally as well as in Malaysia, transgenders are known to face discriminations in employment, and thus face difficulties in establishing financial stability. This situation renders many of the transgender people to turn into sex trade. ${ }^{3,10}$ In Malaysia, about 24,000 mak nyahs are sex workers. ${ }^{7}$ 
Many factors place the mak nyahs at risk for HIV infection. The most commonly recognised factor is involvement in high risk sexual behaviours. These include unprotected sexual intercourse with male partners (be it stable partners, casual partners, or clients). ${ }^{11}$ In addition, commercial sex work is also a source of HIV risk because of having multiple sex partners, inconsistent condom use, sex in the context of alcohol/drugs, and higher payment for unprotected sex. ${ }^{12}$ Knowledge and attitude in HIV/ AIDS could also be the protective factors in reducing HIV-related sexual risks. ${ }^{13,14}$

So far, there have been very few studies that documented HIV-related problems in the mak nyah community in Malaysia. ${ }^{15}$ Teh (2008) has attempted to discuss about HIV-related needs among mak nyahs in Malaysia covering issues such as misconceptions about HIV/AIDS, poor attitude towards HIV-related healthcare services, and HIVrelated needs. However, in qualitative studies, the severity of these problems within the mak nyah communities could not be objectively assessed. ${ }^{3}$

In Malaysia, the Ministry of Health and Global Fund had increased the coverage of its targeted community-based interventions that include among others, sexual transmitted infection (STI) prevention services, information, education and Behaviour Change Communication (BCC), referral to sexual reproductive health (SRH) services, outreach and peer education, and encouraging voluntary HIV testing and counselling. IBBS findings summary from Malaysian Ministry of Health stated that knowledge on HIV transmission among transgenders was $37.2 \%$ of the population in $2009,40.6 \%$ in 2012, and then reduced to $38.1 \%$ in 2012 . The study also noted that the use of condom with the most recent partner among the mak nyah community has improved slightly with $81.2 \%$, compared to $72.5 \%$ in 2012 . However, detailed documentations on specific misconception as well as consistency of condom use were not available. ${ }^{7,16}$

Draman et.al. (2016) has taken the effort to measure the levels of knowledge and attitude towards HIV/AIDS among 30 mak nyah subjects in the Pahang state of Malaysia. It was found that among the subjects, $87.9 \%$ demonstrated good level of knowledge and attitude towards HIV/AIDS. Only level of education was significantly associated with level of knowledge on HIV/AIDS ( $p=0.01)$. Age, occupation, income, and religious status have no influence on the level of knowledge and attitude. However, the paper did not discuss further on HIVrelated risk behaviours among the subjects, and the statistical findings were limited by the small sample size. $^{17}$

IBBS survey found an alarming trend in alcohol and psychotropic drugs used prior to having sex among transgenders with $38.1 \%$ using alcohol and $22 \%$ using drugs in 2012 to $39.5 \%$ using alcohol and $24.1 \%$ using drugs in 2014. These overlapping risks certainly impede the proper use of condom during sexual intercourse. $^{7}$

The objectives of this study were to assess mak nyahs' knowledge and attitude in HIV/AIDS and in what way they are related to the HIV-related risk behaviours through larger cohorts and with qualitative analysis. It is to explore the question whether HIV-related knowledge alone is sufficient to curb the spread of STI and HIV epidemic among mak nyahs in Malaysia.

\section{METHOD}

A cross-sectional study was carried out among Malaysian mak nyahs using validated questionnaires. The research protocol was approved by University Sains Islam Malaysia Research Ethics Committee with the code USIM/REC/0816-17.

\section{Participants}

The target population included all Malaysian mak nyahs aged 18 years and above. Eligible subjects included those who could communicate in Bahasa Malaysia.

The sample size was calculated to be 38 by using the online sample size calculator in OpenEpi software, version 3.01. With a prevalence of 0.61 , precision of $5 \%$ and confidence interval of $95 \%$, the design effect was taken to be 4.0, since respondent-driven sampling method was used. ${ }^{18}$

Subjects were recruited through respondent-driven sampling. To reach the subjects, the initial contact was made through a transgender non-governmental organization to inform mak nyahs from the entire country about the survey. Mak nyahs who were informed about the survey were then encouraged to 
contact and invite other members from the mak nyah communities through phone calls, messages, or social media to participate in the survey.

Detailed written and verbal consent were taken from the subjects, and subjects' anonymity was promised.

For illiterate subjects, the survey form was read out loud. Subjects with inquiries about the survey form were attended immediately by the researchers.

\section{Apparatus/Materials}

The entire survey form was in Bahasa Malaysia. Three questionnaires were used in this survey: (1) the HIV-KQ-18 in Bahasa Malaysia, ${ }^{17}$ (2) the HIV attitude questionnaire in Bahasa Malaysia, ${ }^{17}$ and (3) the HIV Risk-Taking Behaviour Scale (HRBS). ${ }^{19}$ The HRBS questionnaire was translated into Bahasa Malaysia. The translated HRBS questionnaire was reviewed by two physicians who are proficient in both English language and Bahasa Malaysia. Once corrections were made, the three questionnaires were compiled together, and socio-demography inquiry section was added.

The combined survey form was distributed to $10 \mathrm{mak}$ nyahs from a local transgender non-governmental organization for pilot test. The internal consistency was calculated with the software IBM SPSS version 20. Cronbach's alpha for the 18 HIV knowledge items was 0.53 , the 10 HIV attitude items was 0.71 , the 11 -item HIV-Risk Taking Behavior Scale section was 0.66 , with a reliable 5 -item subscale for sexual behaviour risk $(a=0.76)$. The overall internal consistency including all three questionnaires was 0.78 .

The software IBM SPSS version 20 was used for data analysis.

Procedure

A cross-sectional survey was done to assess the HIV/ AIDS knowledge and attitude as well as HIV-related risk behaviors in the mak nyah community in Malaysia.

Three meeting sessions were held among the researchers to ensure a standardized, professional, and mak nyah-friendly approach in interacting with the mak nyahs during the research.
Answers in the survey forms were entered into the software IBM SPSS version 20. Entered data were checked twice against the answers in the survey forms. Data was then cleaned and analyzed with the same software.

Statistical significance was set to be $\mathrm{p}<0.05$. Descriptive statistics, $X^{2}$-test, Pearson's correlation, and multiple regression analysis were used.

\section{RESULTS}

A total of 61 subjects participated in the study. However, after double-checking with all the participants, 7 subjects were removed from the collected surveys, because three were found to be cis -gendered individuals, and three mak nyahs refused to fill up most parts of the survey form.

All of the subjects were Malays and Muslims. Details of the socio-demography profile of the subjects were shown in Table 1. The mean age among the subjects was $39.4(S D=9.72)$ years, where majority of them $(61.1 \%)$ were between the ages of 30 to 39 . More than one-tenth of them $(14.8 \%$ and $3.7 \%)$ were 50 years and above.

Many of the subjects came from and were staying in the East Coast of Peninsular Malaysia (Kelantan, Terengganu, and Pahang states). Most of the subjects were single $(90.6 \%)$, a few were married $(3.8 \%)$. Although more than half of them $(65.8 \%)$ had no financial dependents, some still had to share their income with 2 to 3 dependents ( $9.3 \%$ to $14.8 \%)$.

More than half $(63.5 \%)$ of the subjects received secondary education, $19.2 \%$ of them received tertiary education. The median of their income was 1250 (IqR $=1100$ ). For inquiries on employment, many of them had multiple jobs, which were classified into the categories in Table 1 . One quarter $(25.0 \%)$ of them openly admitted to be sex workers.

Majority $(75.5 \%)$ of the subjects reported to live in stable housing. Living in shelters for the homeless, detention centres, drug intervention centres, and "no fixed places" were usually reported to be either rarely or never.

HIV knowledge

The average score of the 54 subjects' answers was $9.8(S D=4.73)$ out of 18 , ranged from 0 to 16 . When 
the scores were categorized into "adequate knowledge" and "poor knowledge" with the cut-off point of $50.0 \%, 37(68.5 \%)$ of the subjects had adequate knowledge, and 17 (31.5\%) had poor knowledge. Table 2 showed the answers of the mak nyah subjects in knowledge of HIV/AIDS. Most

Table 1 Socio-demography profile of mak nyah subjects

\begin{tabular}{lrr}
\hline Parameters & & Frequency \\
\hline Age & $\mathrm{N}=54, \mathrm{n}(\%)$ \\
Minimum & 19 \\
Maximum & 65 \\
Mean (SD) & $39.4(9.72)$ \\
Median (IqR) & $39.4(5.3)$ \\
$18-19$ & $2(3.7)$ \\
$20-29$ & $6(11.1)$ \\
$30-39$ & $33(61.1)$ \\
$40-49$ & $3(5.6)$ \\
$50-59$ & $8(14.8)$ \\
$60-69$ & $2(3.7)$
\end{tabular}

Kedah
Perlis
Melaka
Wilayah Persekutuan KL
Selangor
Kelantan
Terengganu
Pahang
Johor
Others

Place of stay

$$
\begin{array}{r}
\text { Selangor } \\
\text { Kelantan } \\
\text { Terengganu } \\
\text { Pahang }
\end{array}
$$

Marital status

\begin{tabular}{cr} 
Single \\
Married \\
Living in with male $\quad$ partner \\
Divorced (from traditional \\
$\begin{array}{r}\text { marriage) } \\
\text { In a relationship with a man } \\
\text { (not living together) }\end{array}$ & $2(90.6)$ \\
Monthly income & $1(1.9)$ \\
\hline
\end{tabular}

Place of origin

$(88.7 \%)$ of the subjects were aware that having sex with more than one partner can increase a person's chance of being infected with HIV (item 14).

\begin{tabular}{|c|c|}
\hline Monthly income & $\bar{N}=54, n(\%)$ \\
\hline Minimum & 0 \\
\hline Maximum & 5000 \\
\hline Mean (SD) & $1630(1068.3)$ \\
\hline Median (IqR) & $1250(1100)$ \\
\hline $0-490$ & $4(7.4)$ \\
\hline $500-990$ & $9(16.7)$ \\
\hline $1000-1490$ & $15(27.8)$ \\
\hline $1500-1990$ & $5(9.3)$ \\
\hline $2000-2990$ & $12(22.2)$ \\
\hline $3000-3990$ & $6(11.1)$ \\
\hline $4000-4990$ & $2(3.7)$ \\
\hline 5000 & $1(1.9)$ \\
\hline Number of dependents & $N=54, n(\%)$ \\
\hline 0 & $35(64.8)$ \\
\hline 1 & $3(5.6)$ \\
\hline 2 & $8(14.8)$ \\
\hline 3 & $5(9.3)$ \\
\hline 4 & $1(1.9)$ \\
\hline 5 & $1(1.9)$ \\
\hline 6 & $1(1.9)$ \\
\hline Level of education & $N=52, n(\%)$ \\
\hline Never went to school & $3(5.8)$ \\
\hline Primary school & $6(11.5)$ \\
\hline Secondary school & $33(63.5)$ \\
\hline $\begin{array}{c}\text { Diploma / Form } 6 \text { / } \\
\text { Matriculation }\end{array}$ & $10(19.2)$ \\
\hline Occupation & $N=62^{*}, n(\%)$ \\
\hline Sex worker & $12(25.0)$ \\
\hline $\begin{array}{r}\text { Fashion / cosmetics / } \\
\text { wedding }\end{array}$ & $13(27.1)$ \\
\hline Administrative & $9(18.8)$ \\
\hline Restaurant / culinary & $7(14.6)$ \\
\hline Odd jobs & $7(14.6)$ \\
\hline Entertainment & $6(12.5)$ \\
\hline Business & $5(10.4)$ \\
\hline Hotel & $2(4.2)$ \\
\hline Jobless & $1(2.1)$ \\
\hline
\end{tabular}
More than half $(60.4 \%)$ were aware that anal sex could be a way of transmitting HIV (item 4).

Con't

* Since many subjects work multiple jobs and some were part timers in various fields, the $\mathrm{N}=62$ displayed here is the frequency of all the occupations reported by the subjects. 
Table 2 Knowledge in HIV/AIDS among mak nyah subjects

\begin{tabular}{|c|c|c|c|c|}
\hline$\overline{\text { No. }}$ & Items & $\begin{array}{l}\text { TRUE } \\
\text { n (\%) }\end{array}$ & $\begin{array}{l}\text { FALSE } \\
\text { n (\%) }\end{array}$ & $\begin{array}{l}\text { "I don't know" } \\
\text { n (\%) }\end{array}$ \\
\hline$\overline{1}$ & Coughing and sneezing DO NOT spread HIV. & *33(61.1) & $13(24.5)$ & $7(13.2)$ \\
\hline 2 & $\begin{array}{l}\text { A person can get HIV by sharing a glass of water with someone } \\
\text { who has HIV. }\end{array}$ & $9(17.3)$ & *37 (71.2) & $6(11.5)$ \\
\hline 3 & $\begin{array}{l}\text { Pulling out the penis before a man climaxes/cums keeps a } \\
\text { woman from getting HIV during sex. }\end{array}$ & $14(26.4)$ & *27 (50.9) & $12(22.6)$ \\
\hline 4 & A woman can get HIV if she has anal sex with a man. & *32 (60.4) & $12(22.6)$ & $9(17.0)$ \\
\hline 5 & $\begin{array}{l}\text { Showering, or washing one's genitals/private parts after sex } \\
\text { keeps a person from getting HIV. }\end{array}$ & $29(35.8)$ & *22 (41.5) & $12(22.6)$ \\
\hline 6 & $\begin{array}{l}\text { All pregnant women infected with HIV will have babies born } \\
\text { with AIDS. }\end{array}$ & $18(34.0)$ & *27 (50.9) & $8(15.1)$ \\
\hline 7 & $\begin{array}{l}\text { People who have been infected with HIV quickly show serious } \\
\text { signs of being infected. }\end{array}$ & $12(22.2)$ & *28 (51.9) & $12(22.2)$ \\
\hline 8 & There is a vaccine that can stop adults from getting HIV. & $11(20.4)$ & ${ }^{*} 25(46.3)$ & 17 (31.5) \\
\hline 9 & $\begin{array}{l}\text { People are likely to get HIV by deep kissing, putting their } \\
\text { tongue in their partner's mouth, if their partner has HIV. }\end{array}$ & $15(27.8)$ & *27 (50.9) & $11(20.4)$ \\
\hline 10 & A woman cannot get HIV if she has sex during her period. & $4(7.7)$ & *34 (65.4) & $14(26.9)$ \\
\hline 11 & $\begin{array}{l}\text { There is a female condom that can help decrease a woman's } \\
\text { chance of getting HIV. }\end{array}$ & *34 (65.4) & $9(17.3)$ & $9(17.3)$ \\
\hline 12 & $\begin{array}{l}\text { A natural skin condom works better against HIV than does a } \\
\text { latex condom. }\end{array}$ & $15(28.8)$ & *15 (28.8) & $22(42.3)$ \\
\hline 13 & $\begin{array}{l}\text { A person will NOT get HIV if she or he is taking } \\
\text { otics. }\end{array}$ & 9 (17.6) & *28 (54.9) & $14(27.5)$ \\
\hline 14 & $\begin{array}{l}\text { Having sex with more than one partner can increase a person's } \\
\text { chance of being infected with HIV. }\end{array}$ & $* 47(88.7)$ & 1 (1.9) & $5(9.4)$ \\
\hline 15 & $\begin{array}{l}\text { Taking a test for HIV one week after having sex will tell a per- } \\
\text { son if she or he has HIV. }\end{array}$ & $15(28.8)$ & ${ }^{*} 23(44.2)$ & $14(26.9)$ \\
\hline 16 & $\begin{array}{l}\text { A person can get HIV by sitting in a hot tub or a } \\
\text { swimming pool with a person who has HIV. }\end{array}$ & $2(3.8)$ & *35 (66.0) & $16(30.2)$ \\
\hline 17 & A person can get HIV from oral sex. & *29 (55.8) & $14(26.9)$ & $9(17.3)$ \\
\hline 18 & $\begin{array}{l}\text { Using Vaseline or baby oil with condoms lowers the chance of } \\
\text { getting HIV. }\end{array}$ & $9(17.3)$ & *24 (46.2) & $19(36.5)$ \\
\hline
\end{tabular}

*the correct answer

However, some (35.8\%) still believed that washing the genitals after sex could prevent HIV infection (item 5), and $26.4 \%$ believed that the withdrawal method before ejaculation could prevent HIV infection (item 3). About one-fifth (22.2\%) still believed that HIV infection symptoms will rapidly appear (item 7), and $28.8 \%$ believed that any HIV blood test would give a positive result within one week of infection (item 15). Many subjects also believed that taking antibiotics, using lubricants during sex, and vaccines could prevent HIV infection.

\section{Attitude towards HIV/AIDS}

The mean score of the subjects' attitude towards HIV/AIDS was $5.5(S D=2.85)$. Eight of them obtained a total score of zero and only two subjects scored full marks (a score of 10). When the scores were categorized into "overall positive attitude" and "overall negative attitude" with the cut-off point of $50.0 \%, 37(68.5 \%)$ of the subjects had overall positive attitude, and 17 (31.5\%) had overall negative attitude. 
Table 3 described the answers on the mak nyahs' attitude towards HIV/AIDS. Answers from most of the items showed that the subjects generally had positive attitude towards HIV/AIDS, except for items 6 ("I am loyal to my spouse who was infected through blood transfusion") and 7 ("I am loyal to my spouse who was infected through needle sharing"). Many of the subjects also disagreed with needle exchange programs (item 9).

Table 3 Attitude Towards HIV/AIDS among Mak Nyah Subjects

\begin{tabular}{|c|c|c|c|c|}
\hline \multirow{3}{*}{$\begin{array}{l}\text { No } \\
1 \\
1\end{array}$} & \multirow{3}{*}{$\begin{array}{l}\text { Statement } \\
\text { I am willing to intermingle with HIV/AIDS personnel }\end{array}$} & \multirow[t]{2}{*}{$\begin{array}{c}\text { *Agree } \\
\text { n (\%) }\end{array}$} & \multirow{2}{*}{$\begin{array}{r}\text { Do not } \\
\text { agree } \\
\text { n (\%) }\end{array}$} & \multirow[t]{2}{*}{$\begin{array}{r}\text { Not sure } \\
n(\%)\end{array}$} \\
\hline & & & & \\
\hline & & $38(76.0)$ & $4(8.0)$ & $8(16.0)$ \\
\hline 2 & I am willing to eat food prepared by HIV person & $27(54.0)$ & $8(16.0)$ & $15(30.0)$ \\
\hline 3 & I am willing to share toilet with HIV person & $40(83.3)$ & $3(6.3)$ & $5(10.4)$ \\
\hline 4 & I am willing to support family members with HIV/AIDS & $46(92.0)$ & $2(4.0)$ & $2(4.0)$ \\
\hline 5 & I volunteer for HIV screening test & $38(77.6)$ & $2(4.1)$ & $9(18.4)$ \\
\hline 6 & I am loyal to my spouse who was infected through blood transfusion & $6(12.2)$ & $24(49.0)$ & $19(38.8)$ \\
\hline 7 & I am loyal to my spouse who was infected through needle sharing & $3(6.4)$ & $30(63.8)$ & $14(29.8)$ \\
\hline 8 & $\begin{array}{l}\text { If infected with HIV, as a preventive measure, I am ready to use } \\
\text { condoms }\end{array}$ & $37(77.1)$ & $2(4.2)$ & $9(18.8)$ \\
\hline 9 & $\begin{array}{l}\text { If infected with HIV, as a preventive measure, I will accept needles } \\
\text { exchange programs }\end{array}$ & $19(39.6)$ & $17(35.4)$ & $12(25.0)$ \\
\hline 10 & If infected with HIV, as a preventive measure, I will accept free condon & $42(85.7)$ & $3(6.1)$ & $4(8.2)$ \\
\hline
\end{tabular}

${ }^{*}$ considered positive attitude

\section{HIV-related Risk Behaviours}

None of the subjects scored any risk in the "drug use section" under the HIV-Related Risk Behaviours questionnaire.

Table 4 showed HIV-related risk behaviours (sexual behaviour section only) among the subjects. Seventeen subjects $(33.3 \%, N=51)$ reported to have absolutely no risk behaviour. About a quarter $(25.5 \%$ and $25.0 \%$ respectively) reported to have more than 10 sex partners as well as anal sex (item 11) in the past one month (item 7). Consistent condom use each time they had sex was between $29.4 \%$ and $33.3 \%$ (items 8 to 10$)$. A number of them $(2.0 \%$ to $9.8 \%$ ) never used condoms during sex in the past 1 month.

\section{Statistical associations}

Pearson's correlation between the 3 domains (HIV knowledge, HIV attitude, HIV risk behaviours) was calculated. The correlation between HIV knowledge and attitude was statistically significant, $r(54)=$ $0.289, p=0.034$. It was significant between HIV knowledge and HIV-related risk behaviour as well, $r$ $(54)=0.277, p=0.049$. For HIV attitude and HIVrelated risk behaviour, it was $r(54)=-0.066, p=$
0.647. Comparison between age and HIV-related risk behaviour scores revealed the older the subject, the lower the risk, $r(54)=-0.287, p=0.041$.

Items from the three domains were compared against each other with $X^{2}$ test. There was a significant difference in risk of acquiring HIV infection between those who report to be sex workers and those who do not, $X^{2}(1, N=51)=$ 4.413, $p=0.042$. Whether or not the subjects knew about anal sex as a risk of transmitting HIV, there was still recent history of having anal sex, $X^{2}(1, N=$ $54)=0.342, p=0.585$. Whether or not the subjects knew about having multiple sex partner as a risk factor of transmitting HIV, recent history of having multiple sex partner still existed, $X^{2}(1, N=54)=$ 2.043, $p=0.229$. Attitude towards readiness to use condoms as preventive measures did not lead to using condoms with regular partners, $X^{2}(1, N=54)=$ $0.020, p=1.000$. Attitude towards readiness to use condoms as preventive measures also did not lead to using condoms with casual partners, $X^{2}(1, N=54)=$ $0.541, p=0.560$. Those who answered that they were willing to accept free condoms to prevent HIV transmission were willing to use condoms, $X^{2}(1, N=$ 54) $=19.231, p<0.001$. 
Table 4 HIV-related risk behaviors (sexual behavior section) among mak nyah subjects

\begin{tabular}{|c|c|c|}
\hline$\overline{\text { No }}$ & Item & n (\%) \\
\hline \multirow[t]{7}{*}{1} & $\begin{array}{l}\text { How many people, including clients, } \\
\text { have you had sex with in the last } \\
\text { month? }\end{array}$ & \\
\hline & $\begin{array}{lll}\text { None } \\
\text { Non }\end{array}$ & $22(42.3)$ \\
\hline & One & $3(5.8)$ \\
\hline & Two & $2(3.8)$ \\
\hline & 3-5 people & $5(9.6)$ \\
\hline & 6-10 people & $7(13.5)$ \\
\hline & More than ten people & $13(25.0)$ \\
\hline \multirow[t]{7}{*}{2} & $\begin{array}{l}\text { How often have you used condoms } \\
\text { when having sex with your regular } \\
\text { partner(s) in the last month? }\end{array}$ & \\
\hline & No reg. partner & $23(45.1)$ \\
\hline & Every time & $15(29.4)$ \\
\hline & Often & $2(3.9)$ \\
\hline & Sometimes & $2(3.9)$ \\
\hline & Rarely & $4(7.8)$ \\
\hline & Never & $5(9.8)$ \\
\hline \multirow[t]{7}{*}{3} & $\begin{array}{l}\text { How often did you use condoms when } \\
\text { you had sex with casual partners? }\end{array}$ & \\
\hline & No cas. partners & $23(45.1)$ \\
\hline & Every time & $15(29.4)$ \\
\hline & Often & $1(2.0)$ \\
\hline & Sometimes & $2(3.9)$ \\
\hline & Rarely & $6(11.8)$ \\
\hline & Never & $4(7.8)$ \\
\hline \multirow[t]{7}{*}{4} & $\begin{array}{l}\text { How often have you used condoms } \\
\text { when you have been paid for sex in the } \\
\text { last month? }\end{array}$ & \\
\hline & $\begin{array}{ll}\text { No paid sex } \\
\end{array}$ & $22(43.1)$ \\
\hline & Every time & $17(33.3)$ \\
\hline & Often & $5(9.8)$ \\
\hline & Sometimes & $3(5.9)$ \\
\hline & Rarely & $3(5.9)$ \\
\hline & Never & $1(2.0)$ \\
\hline \multirow[t]{7}{*}{5} & $\begin{array}{l}\text { How many times did you have anal sex } \\
\text { in the last month? }\end{array}$ & \\
\hline & No times & $22(43.1)$ \\
\hline & One time & $5(9.8)$ \\
\hline & Two times & $2(3.9)$ \\
\hline & 3-5 times & $4(7.8)$ \\
\hline & 6-10 times & $5(9.8)$ \\
\hline & More than 10 times & $13(25.5)$ \\
\hline
\end{tabular}

Multiple regression analysis was used to test if knowledge and attitude in HIV/AIDS would predict HIV-risk related behaviours. Together, these two variables did not significantly predict HIV-related high risk behaviours, $\mathrm{F}(2,48)=2.625, \mathrm{p}=0.083, \mathrm{R}^{2}$ $=0.099$. However, HIV knowledge alone significantly predicted HIV-related high risk behaviours $(B=0.320$, $\mathrm{p}=0.030)$, while attitude in HIV/AIDS did not, $(B=-$ $0.155, p=0.283$ )

\section{DISCUSSION}

This was one of the first quantitative studies designed in Malaysia to investigate the knowledge, attitude, and risk behaviours related to HIV/AIDS, as well as the associations between these factors, in the mak nyah community. This study complemented previous studies on Malaysian mak nyahs, where both qualitative and quantitative studies previously were usually done in the west part of Peninsular Malaysia, mainly focusing on the area around Kuala Lumpur. In this present study, majority of the subjects came from the East Coast of Peninsular Malaysia, where socio-demography and cultural elements could differ from other parts of Malaysia. Thus, this study provided a rare picture of mak nyahs and HIV-related issue in this particular geographical area of Malaysia.

In contrary to findings in many other studies (e.g. The UNAIDS Gap Report 2014), homelessness was not a common problem for the subjects in this study. This could be because many of the mak nyahs were willing to share rooms with their mak nyah friends.

The subjects in this study generally still had low levels of knowledge in HIV/AIDS, inadequate attitude towards HIV/AIDS, and high risk in HIV infection. These findings are roughly consistent with the results in previous reports in Malaysia. ${ }^{3,7}$ Another notable finding was the significant difference in attitude when HIV knowledge levels varied. Education on HIV still has to be aggressively carried out in this community to improve its attitude towards HIV, with the hope to reduce stigma among mak nyahs themselves towards mak nyahs who are at risk.

Although only one quarter of them reported to be sex workers, having multiple sex partners and unprotected anal sex were still common among the subjects. Inconsistent condom usage still persisted in this sample of subjects, most likely because the sexual activities were carried out under the influence of alcohol and drugs. ${ }^{7}$ Besides, there was no noticeable difference in consistency of condom use whether the subjects were with casual partners, regular partners, or customers. In addition, Malaysia national survey reported an increase trend in condom use with their last client throughout these few years, but it was a cross-sectional survey and did not report specific condom use behaviours. ${ }^{7}$ This present study inquired condom use behaviours throughout the past one month for sexually active subjects, and it could 
not be concluded that condom use was adequately sufficient to prevent HIV transmission.

Another finding worth noticing in this study is that the HIV-related risk behaviour score reduced in older mak nyahs, similar to a recent study in San Francisco. ${ }^{20}$ Reports from Malaysia so far generally focused on mak nyahs in the younger age groups largely because of their tendency to involve in the sex trade and their risk in HIV/AIDS. As mak nyahs age, their needs in healthcare, psychosocial, and spiritual well beings would change. ${ }^{10}$ More research is needed in discovering the needs in the geriatric mak nyah community in Malaysia.

The most striking result in this study was that, having knowledge in HIV/AIDS did not reduce the HIV-related sexual risks, but instead the risks were significantly increased. This suggests that being educated about HIV/AIDS does not translate into safer sexual practices. In addition, this study also revealed that having knowledge on HIV/AIDS did not result in better attitude, and attitude towards HIV/ AIDS did not affect HIV-related risk behaviours as well. Subjects who were aware of the HIV risk in performing anal sex and having multiple sex partners still remained active in these high risk behaviours. Although those who were willing to accept condoms were willing to use condoms, those who showed positive attitude towards condom use did not practice consistent condom use as they reported. But this could be because possession of condoms is often used by law enforcement as evidence of sex work. ${ }^{3,21}$

The authors in this study would like to suggest for further explorations on the reasons behind these findings. From this study, it could be concluded that the majority of this sample of subjects still engaged in HIV-related high risk sexual behaviours although they reported to have better knowledge in HIV/AIDS compared to another similar study in America. ${ }^{20}$

New approaches must also be explored to reduce the HIV-related risks to zero in this community. Considering the socio-religo-cultural situations of a community, approaches through integrating Islamic religion tenets towards the mak nyah community could be a helpful method, as $80 \%$ of them are Muslim. ${ }^{3,4}$ Studies showed that higher levels of religiosity of transgender subjects was associated with lower levels of HIV-related risk behaviours. ${ }^{22,23}$
Socio-religo-cultural elements help in strengthening the application of knowledge, for instance, in Islam, it is stated that it is sinful to deliberately expose oneself to harm. (The Holy Qur'an 2:195, 6:120) In the recent years, non-governmental organizations and government agencies in Malaysia have just begun to include religious elements in educating the mak nyah community on living healthier lifestyle. ${ }^{24}$ These approaches do not include enforcement of law against mak nyahs, but rather knowledgeenforcement methods through the involvement of voluntary participations. It is hoped that religious belief and practices could help in reducing the HIVrelated risks in the mak nyah community.

Lastly, limitations in this study should also be considered. The use of respondent-driven sampling technique limits the generalizability of this study. The mak nyah community is a rather hidden population in Malaysia, especially those who are involved in the sex trade. Thus it is often difficult to recruit mak nyahs for research studies. This could result in a homogenous sample, and some important issues in the community might be underreported. However, results from this study still could provide significant information that reflects HIV-related issues in the Malaysian mak nyah community.

\section{CONCLUSION}

It is important to provide accurate information about HIV/AIDS to the mak nyah community. Also, the correct attitude about HIV/AIDS should be instilled among them. HIV/AIDS awareness is still poor among the subjects in this study, because HIVrelated sexual risk behaviors still persist although they already have the knowledge about prevention of HIV transmission. It is suggested that, beside the conventional methods of education on HIV/AIDS prevention, Islamic religious and spiritual elements could be added into the education methodology, with the hope that risk behaviour would be further reduced.

\section{REFERENCES}

1. DSM-V. American Psychiatric Association: Diagnostic and Statistical Manual of Mental Disorders, Fifth Edition. Arlington, VA, American Psychiatric Association.2013.

2. Ng E. Malay transsexual loses court bid to change gender Kuala Lumpur, Malaysia: Yahoo! 
News; 2011 [cited 2016 27th August, 2016]. Available from: https://www.yahoo.com/ news/malay-transsexual-loses-court-bidchange-gender-053645639.html.

3. Teh YK. HIV-related needs for safety among male-to-female transsexuals (mak nyah) in Malaysia. SAHARA: Journal of Social Aspects of HIV/AIDS Research Alliance. 2008;5(4):178-85.

4. Wei CL, Baharuddin A, Abdullah R, Abdullah Z, Ern KPC. Transgenderism in malaysia. Journal of Dharma. 2012.

5. UNAIDS. HIV Prevention Gap Report.

Switzerland: Joint United Nations Programme on HIV/AIDS, 2016.

6. Baral SD, Poteat T, Strömdahl S, et al. Worldwide burden of HIV in transgender women: a systematic review and metaanalysis. The Lancet infectious diseases. 2013;13(3):214-22.

7. M.O.H. National Strategic plan: Ending AIDS 2016-2030. Ministry of Health Malaysia, Putrajaya: 2015.

8. Gibson BA, Brown S-E, Rutledge R, et al. Gender identity, healthcare access, and risk reduction among Malaysia's mak nyah community. Global public health. 2016:1-16.

9. UNAIDS. The Gap Report. UNAIDS 2014.

10. Draman S, Suofeiya M, Mohd Rus R, et al. Psycho-social and spiritual backgrounds, experiences, and needs as a transsexual: a qualitative study within Persatuan Insaf Pahang. International Medical Journal Malaysia (IMJM). 2016;15(2):27-36.

11. Nemoto $T$, Bödeker $B$, Iwamoto $M$, Sakata $M$. Practices of receptive and insertive anal sex among transgender women in relation to partner types, sociocultural factors, and background variables. AIDS care. 2014;26 (4):434-40.

12. Benotsch EG, Zimmerman RS, Cathers L, et al. Use of the Internet to meet sexual partners, sexual risk behavior, and mental health in transgender adults. Archives of sexual behavior. 2016;45(3):597-605.

13. Noor SW, Ross MW, Lai D, Risser JM. Drug and sexual HIV risk behaviours related to knowledge of HIV serostatus among injection drug users in Houston, Texas. International journal of STD \& AIDS. 2014;25(2):89-95.

14. Thanavanh $B$, Harun-Or-Rashid $M$, Kasuya $H$, Sakamoto J. Knowledge, attitudes and practices regarding HIV/AIDS among male high school students in Lao People's Democratic Republic. Journal of the International AIDS society. 2013;16(1).

15. Koh K. A Review of HIV/AIDS Research in Malaysia. The Medical journal of Malaysia. 2014;69:68-81.

16. Draman S, Ershad Ahmad Khan E, Muhammad I, et al. The effects of family dynamic to psychological aspects of transsexuals at Kuantan, Pahang in 2012. 2014.

17. Draman S, Suofeiya M, Mohd Hussin MS, et al. Knowledge and Attitude towards HIV/AIDS among transsexuals in Kuantan, Pahang. International Medical Journal Malaysia. 2016;15 (1).

18. Wejnert C, Pham H, Krishna N, Le B, DiNenno E. Estimating design effect and calculating sample size for respondent-driven sampling studies of injection drug users in the United States. AIDS and behavior. 2012;16(4):797-806.

19. Ward J, Darke S, Hall W. The HIV risk-taking behaviour scale (HRBS) manual: National Drug and Alcohol Research Centre, University of New South Wales Sydney; 1990.

20. De Santis JP, Hauglum SD, Deleon DA, Provencio -Vasquez E, Rodriguez AE. HIV Risk Perception, HIV Knowledge, and Sexual Risk Behaviors among Transgender Women in South Florida. Public Health Nursing. 2016.

21. Rhodes $T$, Simić $M$, Baroš $S$, Platt $L$, Žikić $B$. Police violence and sexual risk among female and transvestite sex workers in Serbia: qualitative study. Bmj. 2008;337:a811.

22. Dowshen $\mathrm{N}$, Forke $C M$, Johnson $A K$, et al. Religiosity as a protective factor against HIV risk among young transgender women. Journal of Adolescent Health. 2011;48(4):410-4.

23. Golub SA, Walker JNJ, Longmire-Avital B, Bimbi DS, Parsons JT. The role of religiosity, social support, and stress-related growth in protecting against HIV risk among transgender women. Journal of health psychology. 2010;15(8):113544.

24. Irsyad A. I Was A "Mak Nyah" And Rehab Made Me See How Far I Have Strayed Away From My Religion 2015 [26 April, 2017]. Available from: http://malaysiandigest.com/frontpage/282main-tile/577124-i-was-a-mak-nyah-and-rehabmade-me-see-how-far-i-have-strayed-awayfrom-my-religion.html. 
